\title{
Students' expressive engagement with historical film's moving images in a Maltese secondary history classroom
}

\author{
Alexander Cutajar* - University of Malta
}

\begin{abstract}
This paper arises from research into using historical film in a Maltese secondary history classroom vis-à-vis its impact on student motivation, engagement and historical understanding. The paper outlines and discusses indicators of students' affective and cognitive engagement when responding to and analysing historical film's moving images - that is, extracts from footage of twentieth- and twenty-first century historical events captured live on camera as shown on newsreels, broadcast on television or forming part of a historical documentary. Using a single-site study, data was collected from two cohorts of Year 11 students following the history option programme. Each cohort was taught for an academic year and moving images were used as sources in history lessons. Analysing students' discourse in whole-class dialogues to obtain evidence for student engagement, findings showed different indicators of students' expressive verbal engagement with moving images: asking questions, making spontaneous observations, inserting oneself, establishing associations, and peer interaction. Findings suggest that underlying students' expressive engagement were the visual and auditory appeal of moving images, and classroom talk. Features of classroom talk in which moving images were used were consistent with views of dialogic teaching. Based on this evidence, it is argued that moving images can be used as a tool for engaging students, through classroom talk in a dialogic context, in developing historical understanding. It is also suggested that there is potential for using students' verbal utterances when analysing moving images for assessing learning.
\end{abstract}

Keywords: dialogic teaching; Malta; history classroom; historical understanding; moving images; verbal utterances; oracy; peer interaction

\section{Introduction}

In the image-rich educational environment of a multimedia digital age, learning history involving historical film's moving images is the norm. As Haydn et al. (2015: 248) noted, 'with the advent of the data projector, the Wi-Fi equipped classroom, the memory stick and moving image archives such as YouTube, showing moving-image extracts has become a staple "component" of the history teacher's repertoire'. Additionally, crucially, student use of computers and tablets has opened up to them engagement with historical film's moving images via the internet. In Malta, Year 11 students' historical learning draws heavily upon historical film's moving images in studying twentieth and twenty-first century historical topics such as the world wars, the Cold War, and terrorism. Student acquisition of 'the basic skills necessary for the study of many types of historical evidence' (Directorate for Learning and Assessment Programmes, 2012: 2) 
highlights the central role of historical film's moving images in history lessons - footage of historical events, occurring at points throughout the twentieth and twenty-first centuries, captured live on camera and, for example, then appearing in newsreels, television broadcasts and programmes, or as elements in historical documentaries.

In history education, film often takes the form of fictional representations of the past (Woelders, 2007), dramatized in films such as The Patriot (2000) (Metzger and Suh, 2008) or Schindler's List (1993) (Wineburg, 2001). Researchers emphasize that film, or what Woelders (2007: 146) refers to as 'historically themed media', is a powerful channel, a medium, for directly conveying iconically and aurally historical knowledge (Morgan, 2010; Weinstein, 2001; Woelders, 2007). Marcus and Stoddard (2007: 305) suggest that 'teacher practices with film may influence how students make use of and conceive of the past'. This is in line with Wineburg's (2001) proposition to use films in order to shape historical consciousness and advance students' historical understanding. Moreover, teachers use film in history lessons to develop the multifactorial 'thinking historically' that the history domain involves in areas such as empathy (Marcus, 2005; Marcus and Stoddard, 2007; Metzger and Suh, 2008), historical interpretation and the construction of history (Banham and Hall, 2003; Lang, 2002; Morgan, 2010), bias (Cates, 1990) and a sense of place (Sutton, 2004). Haworth (1976: 160) wrote some forty years ago that:

The teacher needs to understand the implications of the visual evidence and how to educate the child's perception. Although this applies to all pictorial matter it is even more important when the picture moves, for here the dynamics of a moving image, reinforced by sound, can produce effects different from those anticipated by the teacher ...

Cognitive neuroscience supports the use of film in teaching history, as Shlain (2014: 197) indicates: 'television has introduced many stark visualizations; it speaks to both sides of the brain. The televised Vietnam War produced an outrage that would have been much slower had it been described only in print.' It is known from magnetic resonance imaging (MRI) that brain activity during learning intensifies when the auditory and visual are presented together (Beauchamp et al., 2004), echoing Jerome Bruner's (1960) iconic, enactive and symbolic model of learning. Engagement with film is heightened because it is a multimodal experience - something that both teachers and students recognized as heightening engagement (Donnelly, 2013).

While research into the use of moving images in the history classroom has focused mainly on feature or fiction films, less is known about how students engage with moving images and sound (historical film) as defined in this study. In an educational cultural context where students eat, sleep and drink digital visual and aural information via their electronic devices, they comfortably and eagerly relate to historical film's moving images both inside and outside the classroom (Card, 2011). So, the focus of this paper is research on how historical film, with its eyewitness projection of the past, engages students affectively and cognitively, heightening their historical awareness, sensitivity and understanding. The research identified twin indicators of student engagement with historical film's moving images. Findings suggest that central to student stimulation, concentration, engagement and learning from engaging with historical film was its visual and auditory impact in conjunction with stimulated dialogic engagement.

\section{Moving images}

The significance of historical film is that from the 1920s, through cinemas it became the most important public source of information about national and world events 
(Stober, 2008; Walsh, 2005), in newsreels such as British Pathé's news broadcasts, and in documentaries (McKernan, 2008). Newsreels exposed the general public to the full range of current and developing national and international political, social, cultural and sporting events, issues and personalities (McKernan, 2008). From the 1950s, television increasingly supplemented and then superseded cinema news, news broadcasts and documentaries. Television included documentaries and programmes on current and past topics that included historical film as a major element (Dahlgren, 2008; Cassedy et al., 2011). A common element of all presentations including historical film is that they were the programme makers' interpretations of the topic. As sources for student historical study they relate to them understanding that interpretation is a major dimension of their thinking historically.

\section{Engagement}

Active involvement is an important characteristic of student engagement in the 'actual behaviours involved in undertaking schoolwork' (Hufton et al., 2002: 267). Behaviour is one of three indicators of engagement, alongside affect and cognition (Fredricks et al., 2004). Recordable evidence of behavioural engagement includes on-task behaviour, full participation, asking questions, and involvement in all other aspects of dialogics and oracy, including classroom argument, discussion, debate and exposition (Fredricks et al., 2004; Goldspink and Foster, 2013).

Studies of student enjoyment of history lessons highlighted that positive behaviours mirrored the extent and nature of their positive engagement (Harris and Haydn, 2006; Haydn and Harris, 2010; Biddulph and Adey, 2004). Other studies also claim that questioning is a powerful indicator of student engagement, that is, it is a motivational factor. Chin et al. (2002: 540) found that comprehension, prediction, application and planning questions - which they refer to as wonderment questions 'played an important role in engaging the students' minds more actively, engendering productive discussion, and leading to meaningful production of knowledge'. Scardamalia and Bereiter (1992) refer to what they call knowledge-based questions that arise spontaneously from students' deep interest in a subject or from their effort to make sense of the world. Cuccio-Schirripa and Steiner (2000) found that high-interest topics induced students to ask more questions. These findings correspond with claims that interest can be both a significant predictor of engagement (Goldspink and Foster, 2013) and an influence on motivation (Schunk et al., 2010).

Additionally, this research study included individual, as opposed to collective, expressive behaviour as an engagement indicator. Evidence of individual expressive behaviour includes: immediate reactive impressions; the degree of interest and enthusiasm; questioning; substantive contributions to the topic; interaction with peers; and participation in discussions, debates, arguments, exposition and presentation. Such behavioural indicators 'link directly to active participation in learning which is what we most often mean by engagement' (Goldspink and Foster, 2013: 293). 


\section{Research design}

The aim of the research was to understand students' classroom learning - motivation, engagement and historical understanding - involving historical film's moving images, with a focus on expressive engagement. The research design drew upon case study methodology, including a pilot phase. The research programme lasted for three academic years. A teacher-researcher (myself) conducted the research. To ensure objectivity, I was careful to avoid any preconceptions and judgements, both about what occurred in the classroom and about learning outcomes. Sources of data included teacher-student classroom dialogues, student written work and semi-structured group interviews. Research findings on expressive engagement were largely based on teacher-student discourse in whole-class dialogues (Herrenkohl and Guerra, 1998; Engle and Conant, 2002). The research involved an all-ability Year 11 history class in a Maltese state secondary school studying history for three years as an optional subject. Two cohorts of students participated in the research. Being a teacher-researcher, I taught each cohort, including that in the pilot study, for a school year. A major aspect of my pedagogy was whole-class discussion where historical knowledge was coconstructed with students through dialogic teaching (van Boxtel and van Drie, 2013).

My criteria for evaluating the educational value of the course's historical film's moving images were:

- relevance to the topic of the lesson

- trustworthiness of the source

- duration of the moving image

- appropriateness to students' ability level

- clarity of the language used

- the visual clarity of the moving image.

Historical film was used in conjunction with other types of sources. Historical film extracts were chosen from YouTube channels, such as British Pathé, but also from other websites, such as the website of the European Union (http://europa.eu/index_en.htm).

\section{Research findings}

Based on Engle and Conant's (2002) approach to analysing discourse to obtain evidence of engagement, this study investigated aspects of student verbal engagement in lessons when studying historical film's moving images. Analysis of data (see Table 1) revealed five behavioural indicators of student engagement with moving images:

- asking questions

- making spontaneous observations

- making inserting comments

- establishing associations

- peer interaction. 
These findings are presented and discussed below.

Table 1: Indicators of students' engagement with moving images

\begin{tabular}{llc}
\hline Indicators of engagement & \multicolumn{1}{c}{ Description } & $\begin{array}{c}\text { Number } \\
\text { of coded } \\
\text { references }\end{array}$ \\
\hline $\begin{array}{l}\text { Asking questions } \\
\text { Making spontaneous }\end{array}$ & Questions that students ask & 622 \\
observations & $\begin{array}{l}\text { Comments made without teacher } \\
\text { Making inserting comments }\end{array}$ & 346 \\
Establishing associations & Placing oneself in the situation & 18 \\
& $\begin{array}{l}\text { Making a connection between what was } \\
\text { seen or heard and something students } \\
\text { Peer interaction }\end{array}$ & 86 \\
& $\begin{array}{l}\text { already know } \\
\text { Other's comments }\end{array}$ & 126 \\
\hline
\end{tabular}

\section{Asking questions}

The most frequent indicator of student behaviour engagement was questioning, as Fredricks et al. (2004) found. Across all the lessons, the majority of questions by both students and teacher were made during analysis of historical film (see Table 2). In total, students asked 622 questions in relation to moving images.

Table 2: Number and percentage of questions asked by speakers

\begin{tabular}{cccccc}
\hline Cohort & Speakers & $\begin{array}{c}\text { Number of } \\
\text { questions } \\
\text { during } \\
\text { lessons }\end{array}$ & $\begin{array}{c}\text { Percentage } \\
\%\end{array}$ & $\begin{array}{c}\text { Number of } \\
\text { questions } \\
\text { during } \\
\text { analysis }\end{array}$ & $\begin{array}{c}\text { Percentage } \\
\%\end{array}$ \\
\hline \multirow{2}{*}{1} & Students & 501 & 31.8 & 281 & 31.7 \\
& Teacher & 1,074 & 68.2 & 605 & 68.3 \\
\cline { 2 - 6 } & Total & 1,575 & 100 & 886 & 100 \\
\cline { 2 - 6 } 2 & & & & & \\
& Students & 702 & 30.9 & 341 & 71 \\
\cline { 2 - 6 } & Teacher & 1,567 & 69.1 & 835 & 100 \\
\hline
\end{tabular}

Most interestingly, data from this study with regard to student questioning differs markedly from most other research studies, which reported that students' questions are infrequent (White and Gunstone, 1992). Overall, student questions were 17.1 per cent of all their utterances. Although questions occurred throughout each lesson, the majority of students' questions (51.7 per cent) occurred when analysing historical film's moving images - probably a positive, significant indication that moving images stimulated questions related to student interest and engagement.

Analysis of students' engagement with the course's historical film's moving images revealed that particular students consistently asked more questions than others, including students who did not ask any. Unlike other studies requiring students to write down questions in relation to a history text (Logtenberg et al., 2011) or a 
science topic of the researchers' choice (Chin et al., 2002; Scardamalia and Bereiter, 1992), in this study students asked questions out of personal interest and stimulation, rather than because of teacher intervention and prompting.

\section{Making spontaneous observations}

Spontaneous comments also show students' engagement with historical film's moving-image extracts in reaction to what they revealed. Figure 1 details four types of spontaneous verbal observations: asking questions ( $n=129)$; passing instant descriptive comments ( $n=143)$; wonderment comments $(n=58)$; and repeating phrases mentioned in the moving images $(n=16)$. Almost all students $(n=12)$ made some kind of observation.

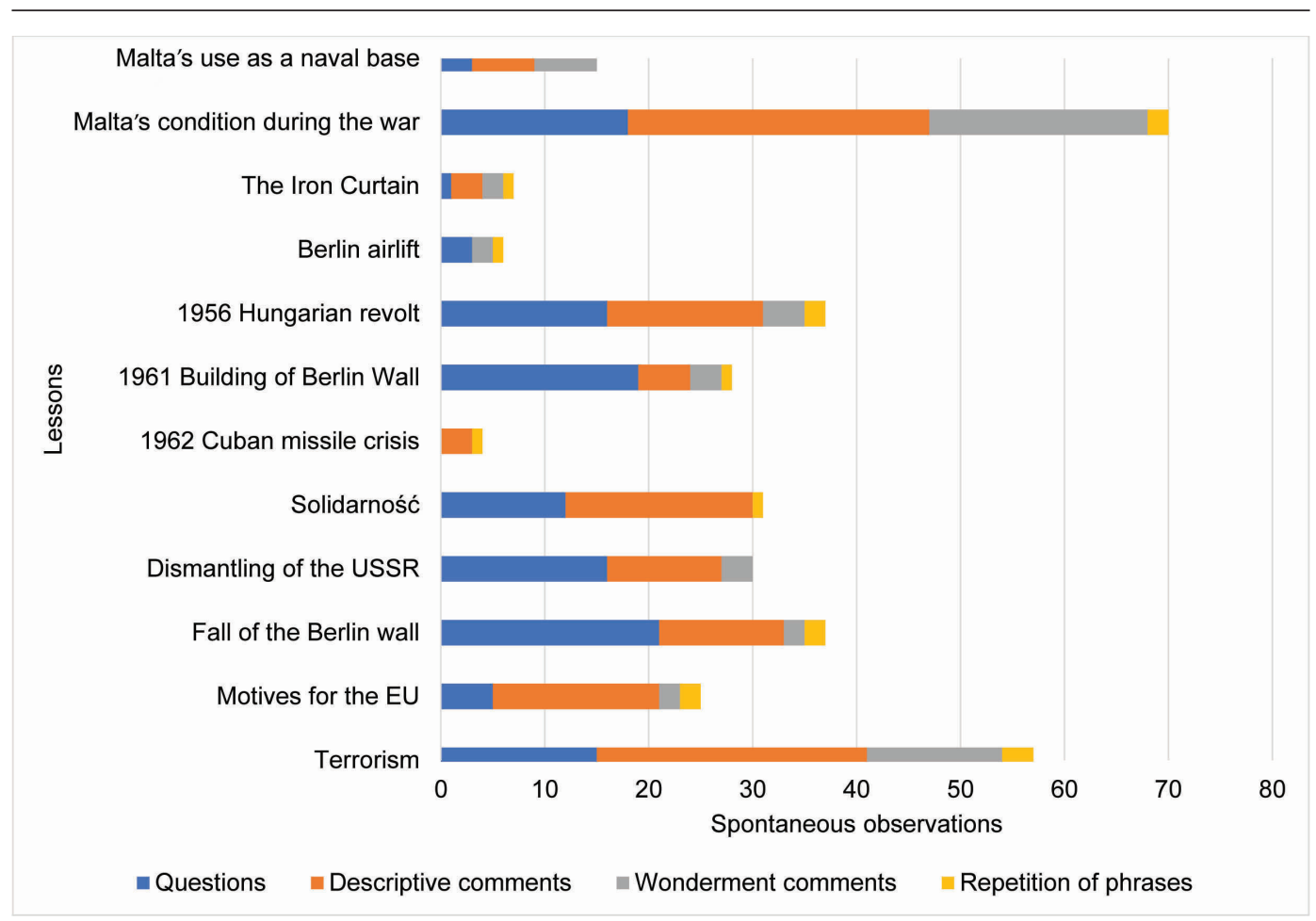

Figure 1: Spontaneous observations while watching moving-image sources

The most frequent form of verbal observation was a descriptive comment in relation to persons, places and objects that the historical film showed. Across all lessons, 11 students passed 143 descriptive comments. The descriptive nature of spontaneous comments was revealed in such verbal utterances as, 'People are going inside the shelter' and 'That is the convoy'. It was in the lesson on 'Terrorism' that students from Cohort 2 passed most descriptive comments, typical examples of which were: 'Who phoned did it on purpose so that it would be broadcast and even they [terrorists] would watch it explode' and 'I think that one must have been [heading] there on purpose'.

Another prevalent way of making an observation was by asking questions $(n=129)$ in relation to what the historical film's moving images showed or what the students heard. Typical spontaneous questions in these lessons were: 'Was he [Kennedy] close to Berlin when he made this speech?' and 'Why are the police spraying water on people?'. Lessons without this kind of questioning were 'The Cuban missile crisis' (both cohorts), 'The Iron Curtain' (Cohort 1) and 'The Berlin airlift' (Cohort 2). 
Wonderment comments $(n=58)$ were made out of astonishment, curiosity and admiration in a spontaneous way. Such comments were expressed in the lesson 'Malta's condition during the war': 'Debris everywhere!' and 'Many people must not have sent their children to school'. In the lesson 'Terrorism', students' wonderment was expressed thus: 'You must be really courageous to kill yourself that way!' and 'What damage it must have caused in the vicinity!'

The final type of spontaneous remark was made by repeating verbatim something uttered by the commentary or an interviewee $(n=16)$. Although the repetition of phrases occurred less frequently than other spontaneous remarks, and were made by only two students, one from each cohort, they nevertheless occurred in nearly all lessons.

What stands out from such comments is that students did not make these comments as a reaction to a teacher's probing. Spontaneous student utterances are a characteristic of dialogic discourse (van Drie and van Boxtel, 2011). By engaging in this way with moving images, students showed that they were closely observing the moving images by watching, listening and being interested, involved and stimulated. Indeed, as in any learning situation in any subject, the occurrence and frequency of such comments would depend on certain variables, such as students' spontaneity and willingness to talk. In fact, not all students reacted spontaneously to the content of moving images. But it may also be the case that such students may think silently, something that could go a long way towards explaining why some students made fewer verbal utterances than others. In this study, while engaged in the learning activity of analysing sequences of historical film, students' minds were teeming with an array of thoughts uttered in a spontaneous think-aloud fashion.

Given the way in which, and frequency with which, students expressed themselves, the method of thinking aloud can safely be described as one way in which students can engage with, and make sense of, the content presented in the moving-image extracts. The think-aloud approach is useful for opening a window on students' minds (Newton, 2012). Even so, students may still not say everything that they think (ibid.), but when carried out in a constructivist classroom such as in this study, the think-aloud approach may go a long way towards instilling in students the confidence to express themselves verbally in class - something that, in the context of moving images, may be done spontaneously. This argument does not imply that teachers should refrain from eliciting student contributions simply because students would offer spontaneous contributions. On the contrary, it should make teachers aware of how to respond to these types of observations whenever they are made by their students.

\section{Making 'inserting' comments}

Sipe (2002) found that young students engaged in storybook reading sometimes assume the role of story characters or bring classmates into the story. Similarly, students in the present study were found to be inserting themselves in the historical film extracts, demonstrated when they made such comments as, 'Thank God that was before I was born, sir' or 'Had I been there [inside a Russian war tank in the streets of Budapest], I would have exploded whatever came in view'. Thus, the term 'inserting' may be applied to this type of verbal engagement and, subsequently, inserting comments can be taken to indicate an engagement with moving images. In the present study, there were 17 such instances. The lesson in which inserting comments were mostly made was 'Terrorism'. Adrian's comment was representative of those of other students: 'Imagine you're inside [the Twin Towers] and you see it [the plane] coming towards you!' From such comments, it was not difficult to notice how some moving images evoked empathetic feelings. While acknowledging the different contexts of the two studies, 
there seems to be similarity in how students engage with the domain-specific content presented during lessons by expressing themselves verbally and becoming one with the story or the extracts in historical film's moving images.

\section{Establishing associations}

Another expressive behaviour that students exhibited involved making verbal connections between an idea presented by the historical film's moving images and something with which they were already familiar. It seemed as though students spontaneously uttered the association that first came to mind upon watching particular content or hearing comments in the historical film extracts - 13 students made this kind of connection.

From a total of 86 remarks coded as 'associations', 26 concerned a historical event. An elaborate association with a historical event was established when watching the Berlin Wall being dismantled. Franklin said, 'This is reminding me of the French Revolution.' He went on to explain that 'the Wall is like the Bastille' because 'it symbolizes the control on the people'. He also pointed out that both the Bastille and the Wall 'were against the people'. For him 'Churchill is like the philosophers'. Kelvin extended this connection by saying that Versailles can be compared to Moscow, 'where the leaders reside', and the peasants can be compared to the workers. Throughout the lessons, students also made a connection with historical figures $(n=12)$ and a country or particular location in a country $(n=18)$.

Hitler was referred to five times by four students in four different lessons. For example, when I explained how, in the post-war elections held in Hungary, the communists did badly but nevertheless slowly managed to find themselves in power, Gavin drew a parallel: 'Like Hitler.' When students established a connection with a country, a typical comment would be: 'It's similar to Libya some time ago.' Adrian made this association in relation to footage from the revolt in Budapest. There were 11 instances when students established an association in the form of an analogy. The most elaborate analogy took place in the lesson 'Malta's use as a naval base', when Kelvin explicated the role of Malta thus: 'It's like, Sir, you have the car and you want to go somewhere far away. You get stuck without fuel and you're hungry. And you've stopped at a place where you can refuel and start off again.' Students also made associations with present-day politicians $(n=4)$, current events $(n=5)$, objects $(n=2)$ and personal interests $(n=8)$.

By making associations, students seemed to have been engaged in the type of reasoning described by Konnikova (2013: 174): 'Usually when we reason, our minds have a tendency to grab any information that seems to be related to the topic, in the process retrieving both relevant cues and those that seem somehow to be connected but may not actually matter.' It may be that students in this study were establishing associations mainly because they were already quite familiar with certain topics, which may not necessarily have been encountered in history lessons.

The knowledge that they had learned over the years in school history, or information that they had come across outside the context of school, was being activated the moment they watched or heard something from the moving-image extracts to which it could be directly related. Interestingly, similar associations were found to be verbalized by students in a study by van Boxtel and van Drie (2012), half of whom were of the same age as the students in this study. The researchers found that initial associations, most of which were concepts or names learned in history lessons, were activated by different terms or visual elements within the text or cartoons that students analysed in the activity. 


\section{Peer interaction}

A final indicator of student engagement with moving-image sources was peer interaction. Findings from this study showed that peer interaction while analysing moving images involved students being responsive to, and building on, each other's utterances by picking up on previous comments, answering peer questions, sharing a divergent opinion, and correcting each other (see Table 3). The fact that 12 students got involved in these types of exchanges shows that students from both cohorts did not hesitate to share a comment in response to something uttered by a peer.

\section{Table 3: Peer interaction}

\begin{tabular}{lcc}
\hline Types of peer interaction & $\begin{array}{c}\text { Number of students } \\
\text { involved in a type of } \\
\text { interaction at least } \\
\text { once }\end{array}$ & $\begin{array}{c}\text { Total number of } \\
\text { coded references } \\
\text { in relation to peer } \\
\text { interaction } \\
\mathbf{N}=\mathbf{1 2 6}\end{array}$ \\
\hline Picking up on a previous comment & 12 & 59 \\
Answering peer questions & 11 & 51 \\
Sharing a divergent opinion & 7 & 8 \\
Correcting each other & 5 & 8 \\
\hline
\end{tabular}

Most frequently, students picked up on an earlier comment in order to extend an idea. These instances consisted of a series of student utterances during which students shared a remark in connection to a peer's previous utterance. Picking up on previous comments resulted in more exchanges than the other types of peer interaction. On 51 occasions, students answered each other's questions before I even offered my answer. Less prevalent instances of peer interaction, though equally important, involved students correcting each other and offering a divergent opinion. Table 4 presents representative examples of students' comments involved in peer exchanges.

Table 4: Representative examples of student utterances for each type of peer interaction

\begin{tabular}{|c|c|c|}
\hline Types of peer interaction & & Representative examples \\
\hline \multirow{8}{*}{$\begin{array}{l}\text { Picking up on a previous } \\
\text { comment }\end{array}$} & Lesson & Malta's condition during the war \\
\hline & Gavin & $\begin{array}{l}\text { Their [Axis planes] engine is a Rolls Royce. The } \\
\text { Americans' is a Mustang. }\end{array}$ \\
\hline & Teacher & Really? \\
\hline & Gavin & Yes, these are Rolls Royce. \\
\hline & Kelvin & Aren't Rolls Royce cars? \\
\hline & Gavin & But the engine is theirs. \\
\hline & Kelvin & So, it's very old! \\
\hline & Gavin & $\begin{array}{l}\text { During the times of the Germans, BMW used to } \\
\text { produce propellers. That's why its logo is in the } \\
\text { form of a propeller. }\end{array}$ \\
\hline
\end{tabular}




\begin{tabular}{|c|c|c|}
\hline \multirow{2}{*}{$\begin{array}{l}\text { Types of peer interaction } \\
\text { Answering peer questions }\end{array}$} & \multicolumn{2}{|r|}{ Representative examples } \\
\hline & Lesson & Solidarność (Solidarity) \\
\hline & Noel & $\begin{array}{l}\text { Why did Stalin and Lenin want people to have } \\
\text { less power when it was supposed that people } \\
\text { have power? }\end{array}$ \\
\hline & Jon & So that they have everything in their hands. \\
\hline \multirow[t]{4}{*}{ Sharing a divergent opinion } & Lesson & Dismantling of the USSR \\
\hline & Jon & $\begin{array}{l}\text { Lenin was the one who started it [communism]? } \\
\text { For sure. }\end{array}$ \\
\hline & Teacher & Yes. \\
\hline & Noel & Wasn't it Stalin? \\
\hline \multirow[t]{4}{*}{ Correcting each other } & Lesson & The building of the Berlin Wall \\
\hline & Gavin & $\begin{array}{l}\text { The East [of Berlin] is on the side of the } \\
\text { Americans. }\end{array}$ \\
\hline & Franklin & That's on the Russians' side. \\
\hline & Kelvin & East is under the Russians. \\
\hline
\end{tabular}

Chin et al. (2002) point out that it is at the stage when students collaborate with peers that they access the zone of proximal development as propounded by Vygotsky (1978). The two most frequent types of peer interaction were picking up on earlier comments and answering peer questions. White and Gunstone (1992: 17) see a motivating factor in students answering peer questions, 'for students are keener to answer their own questions than the teacher's'.

\section{Conclusion}

Two factors seemed to underlie students' expressive engagement and involvement: first, the visual and auditory appeal of moving images; second, classroom talk developed in a dialogic context. That the visual and auditory appeal helped add interest to history was perhaps expressed best by Gavin: 'You won't understand certain things unless you see them happening' (Interview 1); and, 'from pictures you're not going to listen to voices or ideas' (Interview 2). In fact, by means of the moving images, students could see, for example, what taking to the streets in revolt against communist rule in 1956 Hungary or rushing to shelters because of an approaching air raid during the war in Malta meant. They could realize what people's daily lives were like in difficult times, for example, the Maltese during the Second World War and East Europeans under communist rule. Attention to moving images appeared to have been maintained by the accompanying live or voice-over commentaries, which were quite clear and easy to follow. This scenario is of particular significance because, in accordance with the multimedia learning principle (Mayer and Sims, 1994), students were using visual material in tandem with verbally presented narration to construct knowledge.

In a constructivist classroom, student engagement and teacher intervention are primarily achieved through talk (Alexander, 2008). Evidence from this study shows how engagement with moving images was manifested through student-teacher interaction, peer interaction, and students' interaction with subject-specific content. This corresponds with studies showing how such factors increase student behavioural engagement (Cooper, 2014; Crosnoe et al., 2004; Fredricks et al., 2004; Marks, 2000; Patrick et al., 2007; Ryan and Patrick, 2001). In this study, peer interaction was analysed 
in terms of how students contributed to whole-class dialogues when answering peer verbal inputs.

As important as peer interaction is for promoting engagement in the classroom (Davis and McPartland, 2012; Patrick et al., 2007), a significant finding by Nguyen et al. (2016) is that rather than student interaction among peers, for example, through group work, it is the interaction between students and the teacher that matters most for predicting increased student engagement. This has a direct relevance for the history teacher using moving images in the classroom because, as this study has shown, at the basis of analysis of moving images is teacher-student interaction. This scenario emphasizes the key role of the teacher (ibid.) and the centrality of pedagogy as being crucial to eliciting engagement (Harmer and Cates, 2007; Zyngier, 2007). Moreover, these findings suggest the need for pedagogical practices that promote dialogic relationships between students and teachers (Ulmanen et al., 2014).

Evidence of student and teacher talk in the classroom in which moving images were used is consistent with views of dialogic teaching, which is regarded by Alexander (2008) as being collective, reciprocal, supportive, cumulative and purposeful. From the discussion above, certain characteristics that are commensurate with the five principles of dialogic teaching can be identified:

- There was a collective effort at analysing moving images together.

- There was reciprocity as we listened to each other and considered alternative viewpoints.

- A supportive climate made it possible for students to discuss ideas freely.

- Because we were building on each other's ideas in addressing a line of enquiry, talk was cumulative.

- There was a purposeful educational goal from my part in choosing the movingimage extracts and using them in the classroom, linked with the objectives of the history syllabus and the content of the lessons.

Indeed, aware of its demands on the teacher, and on factors particular to classrooms, such as climate, organization, and students' speaking and listening skills, a dialogic pedagogy yields educational benefits because it advances students' learning, understanding, confidence and engagement (ibid.).

Finally, evidence suggests that classroom talk involving moving images can be used as an assessment tool. Among a range of classroom-based assessment tools, teacher and student talk is the most accessible (Ford-Connors et al., 2016). In the present study, talk was a form of assessment, because students' comments were evidence of their developing understandings, which I used to build upon. A key characteristic of this was questioning, which was the most frequent of my verbal inputs. Questioning in the context of dialogic teaching is a strategy for assessing and consolidating understanding (Alexander, 2008). This accords to some extent with formative assessment, which is about responding to student learning 'to identify where the learners are in their learning, where they need to go and how best to get there' (ARG, 2002). In an educational culture that still views students' writing as the most reliable medium for measuring learning (Alexander, 2008), I support Ford-Connors et al. (2016: 50) in arguing for 'a renewed focus on assessment that is grounded in teacher and student talk'. 


\section{Notes on the contributor}

Alexander Cutajar is head of the department of history in a Maltese state secondary school and a visiting lecturer at the Faculty of Education, University of Malta. His $\mathrm{PhD}$ research, carried out at the University of York, considers issues in the history classroom regarding motivation, engagement and historical understanding when using moving images. He is also treasurer of the History Teachers' Association (Malta). He has participated in various international conferences and workshops about history education. His areas of interest include history pedagogy, curriculum and assessment.

\section{References}

Alexander, R. (2008) Towards Dialogic Teaching: Rethinking classroom talk. 4th ed. Thirsk: Dialogos.

ARG (Assessment Reform Group) (2002) Assessment for Learning: 10 principles: Research-based principles to guide classroom practice. Cambridge: Assessment Reform Group. Online. www.hkeaa.edu.hk/DocLibrary/SBA/HKDSE/Eng_DVD/doc/Afl_principles.pdf (accessed 19 June 2017).

Banham, D. and Hall, R. (2003) 'JFK: The medium, the message and the myth'. Teaching History, 113, 6-12.

Beauchamp, M.S., Lee, K.E., Argall, B.D. and Martin, A. (2004) 'Integration of auditory and visual information about objects in superior temporal sulcus'. Neuron, 41 (5), 809-23.

Biddulph, M. and Adey, K. (2004) 'Pupil perceptions of effective teaching and subject relevance in history and geography at Key Stage 3'. Research in Education, 71 (1), 1-8.

Bruner, J.S. (1960) The Process of Education. Cambridge, MA: Harvard University Press.

Card, J. (2011) 'Seeing the point: Using visual sources to understand the arguments for women's suffrage'. Teaching History, 143, 15-19.

Cassedy, L., Flaherty, D. and Fordham, M. (2011) 'Seeing the historical world: Exploring how students perceive the relationship between historical interpretations'. Teaching History, 142: 14-20.

Cates, W.M. (1990) 'Helping students learn to think critically: Detecting and analyzing bias in films'. Social Studies, 81 (1), 15-18.

Chin, C., Brown, D.E. and Bruce, B.C. (2002) 'Student-generated questions: A meaningful aspect of learning in science'. International Journal of Science Education, 24 (5), 521-49.

Cooper, K.S. (2014) 'Eliciting engagement in the high school classroom: A mixed-methods examination of teaching practices'. American Educational Research Journal, 51 (2), 363-402.

Crosnoe, R., Johnson, M.K. and Elder, G.H. (2004) 'Intergenerational bonding in school: The behavioral and contextual correlates of student-teacher relationships'. Sociology of Education, 77 (1), 60-81.

Cuccio-Schirripa, S. and Steiner, H.E. (2000) 'Enhancement and analysis of science question level for middle school students'. Journal of Research in Science Teaching, 37 (2), 210-24.

Dahlgren, P. (2008) 'Television news, visual components of'. In Donsbach, W. (ed.) The International Encyclopedia of Communication (Vol. 11). Malden, MA: Blackwell Publishing, 5088-92.

Davis, M.H. and McPartland, J.M. (2012) 'High school reform and student engagement'. In Christenson, S.L., Reschly, A.L. and Wiley, C. (eds) Handbook of Research on Student Engagement. Boston, MA: Springer, 515-39.

Directorate for Learning and Assessment Programmes (2012) History option syllabus. Government of Malta. Online. https://curriculum.gov.mt/en/Curriculum/Year-9-to-11/Documents/curric_f3_f5/ syllabus_history_opt_f3_f4_f5_2014.pdf (accessed 30 October 2017).

Donnelly, D. (2013) 'Teaching history using feature films: Practitioner acuity and cognitive neuroscientific validation'. International Journal of Historical Learning, Teaching and Research, $12(1), 16-27$.

Engle, R.A. and Conant, F.R. (2002) 'Guiding principles for fostering productive disciplinary engagement: Explaining an emergent argument in a community of learners classroom'. Cognition and Instruction, 20 (4), 399-483.

Ford-Connors, E., Robertson, D.A. and Paratore, J.R. (2016) 'Classroom talk as (in)formative assessment'. Voices from the Middle, 23 (3), 50-7.

Fredricks, J.A., Blumenfeld, P.C. and Paris, A.H. (2004) 'School engagement: Potential of the concept, state of the evidence'. Review of Educational Research, 74 (1), 59-109. 
Goldspink, C. and Foster, M. (2013) 'A conceptual model and set of instruments for measuring student engagement in learning'. Cambridge Journal of Education, 43 (3), 291-311.

Harmer, A.J. and Cates, W.M. (2007) 'Designing for learner engagement in middle school science: Technology, inquiry, and the hierarchies of engagement'. Computers in the Schools: Interdisciplinary Journal of Practice, Theory, and Applied Research, 24 (1-2), 105-24.

Harris, R. and Haydn, T. (2006) 'Pupils' enjoyment of history: What lessons can teachers learn from their pupils?'. Curriculum Journal, 17 (4), 315-33.

Haworth, B. (1976) 'Film in the classroom'. In Smith, P. (ed.) The Historian and Film. Cambridge: Cambridge University Press, 157-68.

Haydn, T. and Harris, R. (2010) 'Pupil perspectives on the purposes and benefits of studying history in high school: A view from the UK'. Journal of Curriculum Studies, 42 (2), 241-61.

Haydn, T., Stephen, A., Arthur, J. and Hunt, M. (2015) Learning to Teach History in the Secondary School: A companion to school experience. 4th ed. London: Routledge.

Herrenkohl, L.R. and Guerra, M.R. (1998) 'Participant structures, scientific discourse, and student engagement in fourth grade'. Cognition and Instruction, 16 (4), 431-73.

Hufton, N.R., Elliott, J.G. and Illushin, L. (2002) 'Educational motivation and engagement: Qualitative accounts from three countries'. British Educational Research Journal, 28 (2), 265-89.

Konnikova, M. (2013) Mastermind: How to think like Sherlock Holmes. New York: Penguin Books.

Lang, S. (2002) 'Mushrooms and snake-oil: Using film at AS/A level'. Teaching History, 108, 44-8.

Logtenberg, A., van Boxtel, C. and van Hout-Wolters, B. (2011) 'Stimulating situational interest and student questioning through three types of historical introductory texts'. European Journal of Psychology of Education, 26 (2), 179-98.

Marcus, A.S. (2005) '"It is as it was": Feature film in the history classroom'. Social Studies, $96(2), 61-7$.

Marcus, A.S. and Stoddard, J.D. (2007) 'Tinsel Town as teacher: Hollywood film in the high school classroom'. History Teacher, 40 (3), 303-30.

Marks, H.M. (2000) 'Student engagement in instructional activity: Patterns in the elementary, middle, and high school years'. American Educational Research Journal, 37 (1), 153-84.

Mayer, R.E. and Sims, V.K. (1994) 'For whom is a picture worth a thousand words? Extensions of a dual-coding theory of multimedia learning'. Journal of Educational Psychology, 86 (3), 389-401.

McKernan, L. (2008) 'Newsreel'. In Donsbach, W. (ed.) The International Encyclopedia of Communication (Vol. 7). Malden, MA: Blackwell Publishing, 3316-18.

Metzger, S.A. and Suh, Y. (2008) 'Significant or safe? Two cases of instructional uses of history feature films'. Theory and Research in Social Education, 36 (1), 88-109.

Morgan, P. (2010) 'How can we deepen and broaden post-16 students' historical engagement with the Holocaust? Developing a rationale and methods for using film'. Teaching History, 141, 27-32.

Newton, D.P. (2012) Teaching for Understanding: What it is and how to do it. 2nd ed. London: Routledge.

Nguyen, T.D., Cannata, M. and Miller, J. (2016) 'Understanding student behavioural engagement: Importance of student interaction with peers and teachers'. The Journal of Educational Research, 111 (2), 163-74.

Patrick, H., Ryan, A. and Kaplan, A. (2007) 'Early adolescents' perceptions of the classroom social environment, motivational beliefs, and engagement'. Journal of Educational Psychology, 99 (1), 83-98

Ryan, A.M. and Patrick, H. (2001) 'The classroom social environment and changes in adolescents' motivation and engagement during middle school'. American Educational Research Journal, 38 (2), 437-60.

Scardamalia, M. and Bereiter, C. (1992) 'Text-based and knowledge-based questioning by children'. Cognition and Instruction, 9 (3), 177-99.

Schunk, D.H., Pintrich, P.R. and Meece, J.L. (2010) Motivation in Education: Theory, research, and applications. 3rd ed. Upper Saddle River, NJ: Pearson Education.

Shlain, L. (2014) Leonardo's Brain: Understanding da Vinci's creative genius. Guilford, CT: Lyons Press.

Sipe, L.R. (2002) 'Talking back and taking over: Young children's expressive engagement during storybook read-alouds'. Reading Teacher, 55 (5), 476-83.

Stober, R. (2008) 'Historic key events and the media'. In Donsbach, W. (ed.) The International Encyclopedia of Communication (Vol. 5). Malden, MA: Blackwell Publishing, 2118-24.

Sutton, P. (2004) 'The wrong beach? Interpretation, location and film'. Teaching History, 116, 62-4.

Ulmanen, S., Soini, T., Pyhältö, K. and Pietarinen, J. (2014) 'Strategies for academic engagement perceived by Finnish sixth and eighth graders'. Cambridge Journal of Education, 44 (3), 425-43. 
van Boxtel, C. and van Drie, J. (2012) "“That's in the time of the Romans!": Knowledge and strategies students use to contextualize historical images and documents'. Cognition and Instruction, 30 (2), 113-45.

van Boxtel, C. and van Drie, J. (2013) 'Historical reasoning in the classroom: What does it look like and how can we enhance it?'. Teaching History, 150, 44-52.

van Drie, J. and van Boxtel, C. (2011) '“In essence I'm only reflecting": Teacher strategies for fostering historical reasoning in whole class discussions'. International Journal of Historical Learning, Teaching and Research, 10 (1), 55-66.

Vygotsky, L.S. (1978) Mind in Society: The development of higher psychological processes. Cambridge, MA: Harvard University Press.

Walsh, B. (2005) Exciting ICT in History. Stafford: Network Educational Press.

Weinstein, P.B. (2001) 'Movies as the gateway to history: The History and Film Project'. The History Teacher, 35 (1), 27-48.

White, R. and Gunstone, R. (1992) Probing Understanding. London: Falmer Press.

Wineburg, S. (2001) Historical Thinking and Other Unnatural Acts: Charting the future of teaching the past. Philadelphia: Temple University Press.

Woelders, A. (2007) '"It makes you think more when you watch things": Scaffolding for historical inquiry using film in the middle school classroom'. Social Studies, 98 (4), 145-52.

Zyngier, D. (2007) 'Listening to teachers - listening to students: Substantive conversations about resistance, empowerment and engagement'. Teachers and Teaching: Theory and Practice, 13 (4), 327-47. 